Секция 9. Углеродные и графеноподобные наноматериалы, дихалькогениды переходных металлов, перовскиты, органические полупроводники, молекулярные системы

\title{
Рекомбинация носителей заряда в аморфных органических полупроводниках: можно ли преодолеть ланжевеновский предел?
}

\section{Новиков С.B. ${ }^{1,2}$, Тамеев А.P. ${ }^{1,2}$}

${ }^{1}$ Институт физической химии и электрохимии им. А.Н. Фрумкина РАН, 119071, Москва, Ленинский просп. 31

${ }^{2}$ Национальный исследовательский университет «Высшая школа экономики», 101000, Москва, Мясниикая ул. 20

DOI 10.34077/Semicond2019-384

Рекомбинация носителей заряда есть один из общих процессов, сопровождающих транспорт носителей в аморфных органических полупроводниках. Таким материалам внутренне присуща сильная пространственная корреляция энергий уровней транспортных центров. В нашей недавней работе [1] построена теория бимолекулярной рекомбинации в аморфных органических полупроводниках, где основной вклад в случайный энергетический ландшафт вносят диполи или квадруполи. Оказалось, что сам по себе энергетический беспорядок не ведет к отклонению константы скорости рекомбинации $\gamma$ от ланжевеновского значения $\gamma_{L}=4 \pi e\left(\mu_{p}+\mu_{n}\right) / \varepsilon$ (здесь $\mu_{p}$ и $\mu_{n}$ - подвижности дырок и электронов, $\varepsilon$ диэлектрическая постоянная среды), а вот пространственная корреляция неизбежно приводит к уменьшению $\gamma$.

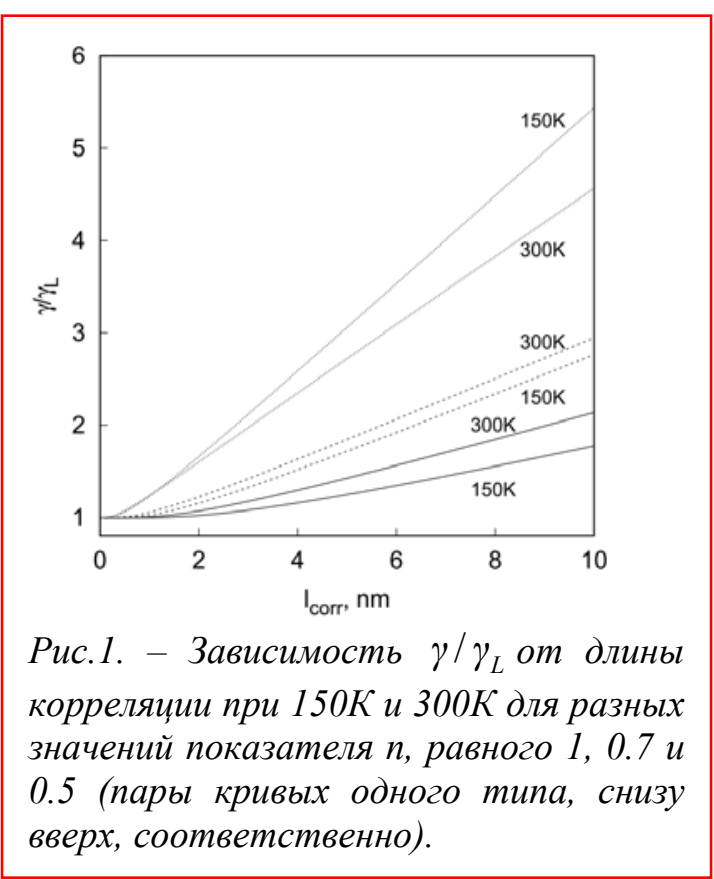

Уменьшение $\gamma$ есть следствие электростатической природы беспорядка (т.е. беспорядка в пространственном распределении электростатического потенциала, генерируемого случайно расположенными и ориентированными диполями и квадруполями), когда локальное понижении энергии дырки одновременно ведет к повышению таковой для электрона. Это ведет к возникновению в коррелированной среде дополнительного отталкивания между электроном и дыркой и, следовательно, к замедлению рекомбинации. Коррелированный энергетический беспорядок с противоположным свойством (симбатное изменение случайных энергий электрона и дырки) приведет к дополнительному притяжению носителей и увеличению $\gamma$. Такая ситуация реализуется в материалах с конформационным беспорядком [2], где можно ожидать увеличения $\gamma$ по сравнению с ланжевеновским пределом, а значит и роста эффективности органических светодиодов на их основе.

На Рис. 1 показаны результаты расчета для конформационного беспорядка с корреляционной функцией случайной энергии вида $C(r) \propto \exp \left(-\left(r / l_{\text {corr }}\right)^{n}\right)$. Для ожидаемых значений $l_{\text {corr }} \approx 1-2$ нм возможно увеличение $\gamma$ на $20 \%$ - $50 \%$ по сравнению с $\gamma_{L}$.

Работа выполнена при финансовой поддержке проекта РФФИ 16-29-06423_офи-м и Программы фундаментальных исследований НИУ ВШЭ.

[1] S.V. Novikov, J. Phys. Chem. C, 122, 22856 (2018).

[2] A. Massé et al., Phys. Rev. B, 95, 115204 (2017). 